\title{
ENVIRONMENTAL CONSIDERATIONS OF LARGE WASTEWATER TREATMENT PLANTS - THE CITY OF NIŠ CASE STUDY
}

\author{
UDC 628.32.034(497.11Niš)
}

\author{
Dejan Vasović ${ }^{1}$, Sandra Stanković ${ }^{2}$, Ljiljana Takić ${ }^{3}$ \\ ${ }^{1}$ University of Niš, Faculty of Occupational Safety, Niš, Serbia \\ ${ }^{2}$ University of Niš, Innovation Center, Niš, Serbia \\ ${ }^{3}$ University of Niš, Faculty of Technology in Leskovac, Serbia
}

\begin{abstract}
Nowadays, the Republic of Serbia is at the bottom of the scale of European countries in terms of public utility equipment of the respective communal infrastructure particularly within the area of wastewater collection and treatment. The current situation in the area of water resources management in the Republic of Serbia indicates that the basic problems are insufficient construction of sewerage infrastructure in cities, i.e. insufficient coverage with the sewerage network of users connected to either public or private water supply network, followed by an insufficient number of constructed and operative wastewater treatment plants. In this sense, a particular problem is a requirement for relatively large initial investments in wastewater collection and treatment sector. Also, a special difficulty is the low price of delivered and channeled water within the existing system of public utilities, which is insufficient to provide maintenance of the existing water supply and sewage systems, regardless the future development and improvement of the existing system. Currently, only $10 \%$ of total produced wastewater quantity is treated in the Republic of Serbia, with different procedures and with uneven and, most often, insufficient purification effects. In addition to wastewater generated by the population (i.e. households connected to the sewer system), the special problem is the inadequate treatment of industrial wastewater. On the other hand, disposition of treated wastewater, disposal of separated sludge from the treatment process, odor and pest control, noise control, working conditions, etc. are significant challenges for the scientists, professionals and operators. Therefore, the aim of this paper is to comprehensively examine all environmental aspects on the example of a large wastewater treatment plant which is to be gained by the city of Niš, in the very near future.
\end{abstract}

Key words: large wastewater treatment plant, environmental impact, the City of Niš

Received April 11, 2019 / Accepted April 26, 2019

Corresponding author: Dejan Vasović

University of Niš, Faculty of Occupational Safety, Čarnojevića 10A, 18000 Niš, Serbia

E-mail: dejan.vasovic@znrfak.ni.ac.rs 


\section{INTRODUCTION}

There is no doubt that the European Union gives significant attention to water regime issues. This is reflected both by detailed, constantly revisited regulation, in order to keep it up to date, and numerous heavily financed activities at the transnational, national, regional and local scale, intended equally to political, organizational, technical, environmental and financial parts influencing water regime.

Regarding the legislative, the first wave of EU water directed legislation (like Surface Water Directive) was announced in 1975, primarily targeting the quality of the potable water sources (like surface water bodies, i.e. rivers and lakes). It also sets bindings on quality targets, like quality objectives on fish waters, shellfish waters, bathing waters and groundwater quality [1]. The second wave of legislation comes in the early nineties, addressing urban and agricultural pollution in water primarily by nitrates from agriculture and other sources. The exponents of this are the Urban Waste Water Treatment Directive and the Nitrates Directive $[2,3]$. The European Union significantly rethought its water policy during the late nineties, as preparation for the third wave. Whilst previous EU actions of the past such as the Drinking Water Directive and the Urban Waste Water Directive can well be considered milestones in this field, European Water Policy has to address the increasing awareness of citizens and other involved parties for their water [4, 5]. At the same time, water policy and water management should address these problems in a coherent way. This is why the new European water policy was developed in an open consultation process involving all interested parties.

The result of that process was the new EU Water Framework Directive of the European Parliament and of the Council of 23 October 2000. This Directive establishes a framework for community action in the field of water policy and imposes extensive changes in regulations and monitoring programme [6]. It should be seen as a common approach with respect to interpretation, goals, legislative principles and methods aimed at protecting chemical, biological, hydrological, morphological and other ecosystems functions of:

- inland surface waters (rivers, lakes, canals and other heavily modified water bodies, e.g. reservoirs),

- transitional waters (like estuaries \& coastal lagoons),

- coastal waters,

- water dependent ecosystems and

- chemical status and the volume of groundwater.

The Water Framework Directive represents the most significant piece of European legislation to date dealing with water quality and quantity. It set 2027 as the last deadline for achieving good ecological status. The ecological status and ecological potential are determined on the basis of parameters classified into the following elements of quality:

- biological

- chemical and physical-chemical of relevance to biological elements for the given the type of surface water body

- hydro-morphological that are relevant to biological elements for a given category of surface water i.e. given type of surface water body.

The ecological status of rivers and lakes is classified as excellent (I), good (II) and moderate (III). All surface waters which have ecological status or ecological potential lower than moderate are classified as poor (IV) or bad (V). The illustration of ecological status classes is shown in Figure 1. 


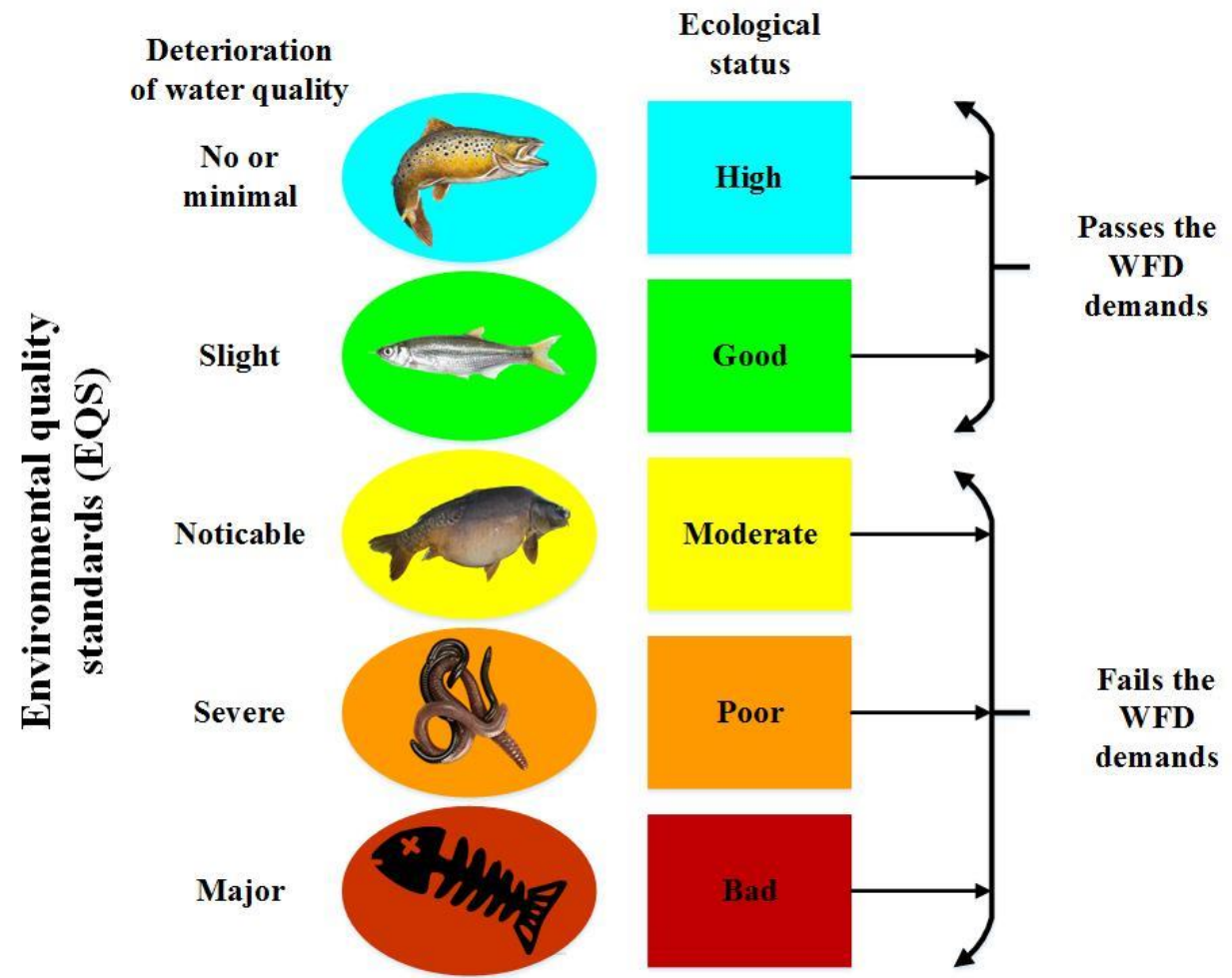

Fig. 1 The basic division of ecological status classes

The assignment of a particular ecological status or potential to an observed water body depends on the state of the biological quality elements that are most affected by anthropogenic activities, except in cases where the results of the monitoring of the physicochemical or hydromorphological quality elements indicate a lower status class. Therefore, for a quality classification scheme based on quality elements, one can say that it is a "one-out all-out" system. Biological, supporting hydro-morphological and physicochemical quality elements were used in the EU Member States in assessing the ecological status/potential of their water bodies.

\section{THE EXPERIMENTAL}

The City of Niš represents an administrative, economic, educational and traffic center of Niš county, with settlements distributed on both riverbanks of the Nišava River, about $10 \mathrm{~km}$ from the embouchure area, i.e. confluence to the Južna Morava River. The existing pressure from households, industry and other sources is roughly expressed to approx. 300.000 PE (population equivalent). The existing sewerage system provides adequate wastewater evacuation from the settled area, although the percentage of the households connected to the sewage system is still lower than the percentage of the households connected to the public water supply. The significant portion of the sewage system is 
technically constructed as a combined system, particularly within the old city area, while the blocks are characterized by separate sewers. The city of Niš is considered to an important source of the different kind of pollutants that endangers the Nišava river quality, particularly in the sense of biological oxygen demand, suspended solids, chemical oxygen demand, total organic carbon, nutrients (nitrogen and phosphate compounds) and microbiological parameters (fecal contaminants) [7].

The City of Niš consists of 5 (five) municipalities: Mediana (central municipality), Palilula, Crveni Krst, Pantelej, and Niška Banja. While the first four municipalities make, in some way, united and compact central city area, the fifth one - Niška Banja (a famous spa center) is a quite distant (about $10 \mathrm{~km}$ east) from the city center, so it can be considered as a separate entity in terms of wastewater collection and treatment. Some characteristics important for wastewater plant design are listed below:

- Total population: approx. 280000 inhabitants (approx. $300000 \mathrm{PE}$ )

- Geographic coordinates: latitude $43^{\circ} 19^{\prime}$ North, longitude $21^{\circ} 54^{\prime}$ East

- Highest point altitude - $1523 \mathrm{~m}$, lowest point - $173 \mathrm{~m}$ (village Trupale where is located main sewage disposal point and where future wastewater treatment plant is to be located)

- Annual average temperature $-11,2^{\circ} \mathrm{C}$ - this data is particularly important when considering biological wastewater treatment

- Average annual precipitation of 567 millimeters

- Total surface of settlements - approx. $180 \mathrm{~km}^{2}$

In a historical sense, the first aqueducts within the area were built in the $1^{\text {st }}$ century A.D. They were $8 \mathrm{~km}$ long, with massive walls $(1.65 \mathrm{~m}$ tick). Later, in the period of Ottoman rule (15th century), some public bathrooms and public fountains were built there. When Serbian troops liberated Nis in 1878, water supply was rather poor. The situation improved by digging a few tube wells; however, a water supply problem was completely solved in 1937, when the city of Niš got its first modern water supply system. With some modifications and upgrades that system still exists nowadays. Since the first aqueduct was built in the first century $\mathrm{AD}$, there had been no tracks about water sewerage until 1922, when a preliminary design of a sewage system was finally made. According to that design, the first modern sewage system was built in 1928, consisting of two main discharge points. During the following years, these sewage systems experienced some modifications, but the main pipes are the mirror of an 88-year old design. The institutions currently responsible for wastewater management in the city of Niš are: Public Utility Company "Naissus", Public Water Company "Srbijavode", Ministry of Environmental Protection, and the local government. It should be borne in mind that the economic and technical demands of these issues greatly exceed the capabilities of local authorities.

In terms of water quality monitoring activities of Serbian Environmental Protection Agency (SEPA), there are two measuring stations on the Nišava (Dimitrovgrad - upstream and Niš - downstream), under SEPA's jurisdiction [7]. The results of the ecological status parameters observed on these measuring stations clearly show the negative impact of the untreated wastewaters along the Nišava course, particularly after the discharge of untreated wastewaters from the City of Nis. This issue has been discussed in numerous scientific papers $[8,9]$. Besides these monitoring stations, the local committee for environmental protection continuously performs measurements on different sites, in order to obtain a more precise image of the ecological status of the Nišava [10]. The City of Niš is located on both 
banks of the Nišava, close to its inflow point to the Južna Morava (the Nišava is the largest tributary of the Južna Morava). At the Niš profile, the Nišava could be classified as a semimature river, according to its hydro-morphological characteristics [11]. Unfortunately, the city of Niš is considered as the heavy polluter of the Nišava River. There have been significant efforts to solve the pollution problem. The results are an adopted feasibility study, selected location of the wastewater treatment plant, and approved technological design [12].

\section{RESULTS AND DISCUSSION}

In the process of pre-engineering design of wastewater treatment plant, it is of paramount importance to describe the following issues:

- wastewater recipient (qualitative and quantitative characteristics, seasonal variations, dependence on ecosystem and populations.), in this case, the Nišava River,

- pressure derived from the settlements (qualitative and quantitative characteristics, daily oscillations, percentage of households vs. industry wastewater, etc.), in this case, the City of Niš,

- potential wastewater treatment solution, depending on the available surface, gravitational conditions, operation and maintenance costs, calculated purification level, etc.,

- the final solution for sludge separation and expected amounts,

- stakeholder interests.

As mentioned before, sanitary conditions of the Nišava River, primarily in terms of the biological and microbiological quality, are unsatisfactory during the major part of the year. Today, all the wastewaters from the City of Niš are eliminated through three outlets on the left and the right side of the Nišava River (one large main outlet and two auxiliary smaller ones). Of at least the same importance is the fact that the upstream flow of the Nišava is already significantly contaminated by the pollution from the settlements. In addition, a very important characteristic of the river is a very small minimal monthly flow rate with the probability of occurrence of $95 \%\left(\mathrm{Q}_{95 \%}\right)$ which is only $2,5-4 \mathrm{~m}^{3} / \mathrm{s}[15]$. As a consequence of all these factors, before inflow into the Južna Morava, the Nišava River quality falls into IV category, according to many parameters.

As we have previously concluded, the core problem in the city of Niš (pertaining to water protection) is the lack of wastewater treatment facility. By the construction of the treatment facility, the total wastewater amount (including communal, industrial and atmospheric) would be collected and processed before being discharged into the Nišava. It is expected that the disturbed quality of the river could be improved up to the required level of river quality by the construction of the wastewater treatment facility. Of course, the required level of river quality relies upon the purification level, which depends on settlement characteristics. In this sense, the basic settlement information is shown in Table 1. 
Table 1 Basic community information

\begin{tabular}{|c|c|c|c|c|}
\hline Demographics & $\begin{array}{l}\text { Resources } \\
\text { (available) }\end{array}$ & $\begin{array}{l}\text { Hydro/ } \\
\text { Meteorological }\end{array}$ & Financial & On-site \\
\hline Base year & Construction & Precipitation/ & Base year & Soil type \\
\hline Population & equipment & Evaporation rate & Number of years & Percolation rate \\
\hline Population growth & O\&M equipment & Minimum temperature & Currency name & Water table \\
\hline Rate & Process & Average temperature & Currency exchange & depth \\
\hline Population density & materials & Precipitation & Interest rate & Water rate \\
\hline Persons per dwelling & Energy resources & distribution & Inflation rate & oscillations \\
\hline $\begin{array}{l}\text { Land area growth } \\
\text { rate }\end{array}$ & $\begin{array}{l}\text { Labor } \\
\text { Chemicals }\end{array}$ & $\begin{array}{l}\text { Wastewater quality } \\
\text { Wastewater quantity }\end{array}$ & $\begin{array}{l}\text { Construction cost } \\
\text { indices }\end{array}$ & $\begin{array}{l}\text { Distance to GW } \\
\text { source }\end{array}$ \\
\hline Water use & Laboratory & Collection system & O\&M cost indices & Water regime \\
\hline Water use growth & equipment & & Treatment facility & Close dwellings \\
\hline & Process control & & land value & Wind direction \\
\hline Wastewater rate & equipment & & Reuse land value & \\
\hline $\begin{array}{l}\text { Wastewater growth } \\
\text { rate }\end{array}$ & $\begin{array}{l}\text { O\&M } \\
\text { management }\end{array}$ & & & \\
\hline
\end{tabular}

On the other hand, planned wastewater treatment facility should be able to operate with total organic loading of at least $300000 \mathrm{PE}$ (population equivalent). The present situation is that approximately 250.000 inhabitants are connected to a sewage system and that the industry contributes to total number of 300.000 PE. There are reasons to believe that these numbers are likely to increase.

Table 2 shows a defined influent flow rate and the concentrations of characteristic parameters. Maximum inflow rate is defined as approx. $2 \mathrm{~m}^{3} / \mathrm{s}$, or approx. 2 x Qn. Also, there is an assumption that specific flow rate, expressed in 1/PE*day, will decrease from current approx. $3001 / \mathrm{PE}^{*}$ day, to $2001 / \mathrm{PE}$ day (thanks to the water saving measures, including both technological and educational).

Table 2 Influent flow rate and relevant parameters [12]

\begin{tabular}{lcr}
\hline Parameter & Unit & $\begin{array}{c}\text { Projected } \\
\text { situation }\end{array}$ \\
\hline Total organic load & $\mathrm{PE}$ & 300000 \\
Average flow & $\mathrm{m}^{3} / \mathrm{h}$ & 3276 \\
Adopted flow & $\mathrm{m}^{3} / \mathrm{h}$ & 3300 \\
COD & $\mathrm{kg} / \mathrm{d}$ & 31750 \\
BOD 5 & $\mathrm{~kg} / \mathrm{d}$ & 15000 \\
SS & $\mathrm{kg} / \mathrm{d}$ & 17000 \\
Total N & $\mathrm{kg} / \mathrm{d}$ & 3000 \\
Total P & $\mathrm{kg} / \mathrm{d}$ & 375 \\
COD & $\mathrm{mg} / \mathrm{l}$ & 400 \\
BOD & $\mathrm{mg} / \mathrm{l}$ & 200 \\
SS & $\mathrm{mg} / \mathrm{l}$ & 219 \\
Total N & $\mathrm{mg} / \mathrm{l}$ & 38 \\
Total P & $\mathrm{mg} / \mathrm{l}$ & 4,7 \\
${\text { COD} / B_{0}}_{5}$ & & 2 \\
BOD $_{5} /$ Total N & & 5,0 \\
BOD $_{5} /$ Total P & & 40 \\
\hline
\end{tabular}


The main input parameters considered during technology selection are influent flow, influent concentrations, community information, etc. (see Table 1 and 2). The effluent quality demands yet another important condition, as shown in Table 3.

Table 3 Effluent demands (non-sensitive areas) [13, 14]

\begin{tabular}{lcc}
\hline Parameter & Measurement unit & Value \\
\hline COD & $\mathrm{mg} / \mathrm{l}$ & 125 \\
$\mathrm{BOD}_{5}$ & $\mathrm{mg} / \mathrm{l}$ & 25 \\
$\mathrm{SS}$ & $\mathrm{mg} / \mathrm{l}$ & 35 \\
Total N & $\mathrm{mg} / \mathrm{l}$ & N/A \\
$\mathrm{NH}_{4}-\mathrm{N}$ & $\mathrm{mg} / \mathrm{l}$ & N/A \\
Total P & $\mathrm{mg} / \mathrm{l}$ & N/A \\
\hline
\end{tabular}

Effluent standards are one of the most important to be considered (besides finances, i.e. investment, operation and maintenance costs). Also, there is a need to constantly monitor water quality within the mixture of treated wastewater and river water (i.e. after the discharge of treated wastewater), in order to keep it in a desired ecological status class, and also to monitor purification level of the facility.

According to the Regulation on determining the water bodies of surface water and groundwater, the Regulation on reference conditions of surface water types, and the Regulation on the parameters of ecological and chemical status of surface water and the parameters of chemical and quantitative status of groundwater, the Nišava water course at the city of Niš profile is categorized as type II water body (relatively large lowland rivers, with domination of middle layers), which means that the thresholds between ecological status classes for this type of water body can be applied (see Table 4) [10].

Table 4 Physical-chemical parameters of ecological status classes for type 2 water body

\begin{tabular}{lccccc}
\hline \multicolumn{1}{c}{ Parameter } & Unit & \multicolumn{3}{c}{ Thresholds between ecological status classes } \\
\cline { 3 - 6 } & & I-II & II-III & III-IV & IV-V \\
\hline pH value & & $6.5-8.5$ & $6.5-8.5$ & $6.5-8.5$ & $<6.5 ;>8.5$ \\
Dissolved oxygen & $\mathrm{mg} \mathrm{l}^{-1}$ & 8.5 & 7.0 & 5.0 & 4.0 \\
BOD $_{5}$ & $\mathrm{mg} \mathrm{l}^{-1}$ & 1.8 & 4.5 & 6.0 & 20.0 \\
Total organic carbon (TOC) & $\mathrm{mg} \mathrm{l}^{-1}$ & 2.0 & 5.0 & 7.0 & 23.0 \\
Ammonium ion $\left(\mathrm{NH}_{4}-\mathrm{N}\right)$ & $\mathrm{mg} \mathrm{l}^{-1}$ & 0.05 & 0.1 & 0.8 & 1.0 \\
Nitrates $\left(\mathrm{NO}_{3}-\mathrm{N}\right)$ & $\mathrm{mg} \mathrm{l}^{-1}$ & 1.50 & 3.00 & 6.00 & 15.00 \\
Orthophosphates $\left(\mathrm{PO}_{4}\right.$-P) & $\mathrm{mg} \mathrm{l}^{-1}$ & 0.02 & 0.1 & 0.2 & 0.5 \\
Total dissolved phosphorus (P) & $\mathrm{mg} \mathrm{l}^{-1}$ & 0.05 & 0.2 & 0.4 & 1.0 \\
Chlorides & $\mathrm{mg} \mathrm{l}^{-1}$ & 50 & 100 & - & - \\
\hline
\end{tabular}

During the selection process, it is necessary to take into account land configuration and enlargement possibilities (if needed). Bearing these considerations in mind, a selected wastewater treatment facility should be based on reliable technologies, already tested worldwide, and without complicated structures.

Criteria that should also be analyzed are listed as following:

1. Environmental impact assessment

2. Stability of the wastewater treatment process - the process should be easy to control 
3. Flexibility of the process - related to changes that might occur in terms of hydraulic and organic loading

4. Investment and maintenance costs should be as low as possible

5. Selected technology shouldn't be complicated for operators

6. Control systems should be as simple as possible

7. Odor and pests control must be implemented

8. Occupational conditions must be at a satisfactory level

The primary goal of selected wastewater purification (treatment) method is to meet effluent demands, while the secondary goal (but also of paramount importance) refers to sludge treatment and disposal. The possible wastewater treatment design is illustrated in Figure 2.

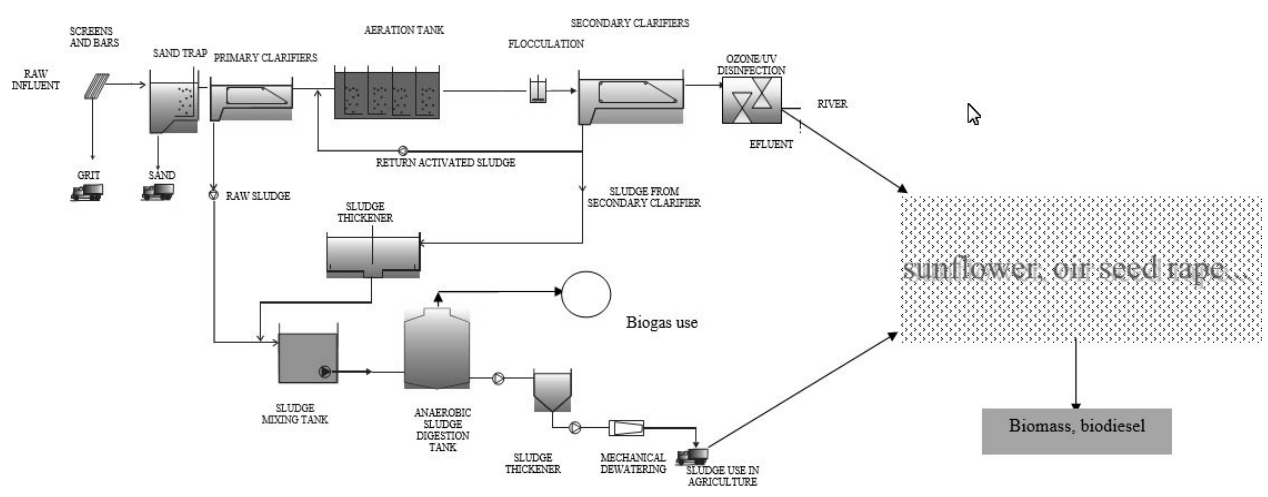

Fig 2 The possible wastewater design (modified from [12])

Proposed technology relies on preliminary treatment, primary treatment, secondary biological treatment, and sludge processing line. Preliminary treatment includes screens, bars and grit removal chamber. Primary treatment contains primary clarifiers with gravimetric deposition. Biological - secondary treatment includes CAS process with additional sedimentation in secondary clarifier in order to improve $\mathrm{BOD}_{5}$ removal. Tertiary treatment includes disinfection - ozone or UV radiation.

Among other recommendations mentioned here, there are several options to modify wastewater solving problem by introducing the following tools:

- Prevention and minimization: introducing water saving measures, both technological and educational. As noticed, average water usage per capita is quite high which causes significant wastewater generation. Also, banning undesirable compounds and pre-treatment enforcing will eventually reduce the concentrations of undesirable compounds in wastewater to be treated.).

- Treatment to re-use: there is a possibility of converting separated sludge to some kind of additional, auxiliary land fertilizer. Also, there is a need to discuss potential effluent usage in agriculture for irrigation. Regarding macro and microclimate factors in the city of Niš vicinity, a certain amount of effluent can be used in this way during the vegetation period. It should be kept in mind that water demand for irrigation is the highest during summer (i.e. during the months with the lowest river 
flow rate), while the river self-purification capacity is the lowest. This kind of effluent usage (usage only for industrial plants, avoiding the possibility that pathogens brake into human food chain) could improve biomass growth, providing additional fuel that could be used during the winter (e.g. for anaerobic digester heating).

- Natural self-purification: construction of small dams, small lagoons, or creating artificial wetlands. Small lagoons with carefully selected plants seem the most appropriate since they could be used for recreation as well. Artificial wetlands can play a significant role in the final nutrient removal stage, in addition to the tertiary stage of wastewater treatment [16].

This way, operational costs would be significantly reduced. Also, there would be an increase in purification rate. The final outcome would be a reduction in sludge production since the sewage system is observed through both water production and ecosystem water balance.

\section{CONCLUSION}

Considering the broadness of this topic, integral water quality management has become significant for the implementation of sustainable water quality actions for the Nišava River basin, particularly in terms of pollution control in Niš downstream area and the management of freshwater resources quality in upstream Nišava river basin. The DPSIR conceptual framework can be used in all phases of sustainable water quality utility design and implementation, especially while evaluating the effects of pressures on ecological status, analyzing future actions on the improvement of the aquatic ecosystem status, and defining cost-effective monitoring programs. This paper stresses the importance of application of wastewater treatment processes, sludge processing, as well as the other fundamentals and principles of sustainable water quality management.

The globally adopted integrated water resources management policy relies on the principle of sustainable development goal No 6 that obliges all the countries in the world (the Republic of Serbia is obligated too) to prepare national action plans for implementation of the adopted principles into operative action strategies at national, regional and local level. In addition, the countries are obligated to foster the development of approaches, measures, and methods for sustainable water resource management, with particular regard to transboundary river basins, having in mind that the Nišava river basin certainly falls within this category.

Acknowledgement: The presented research is a part of the projects III 44006, III 42006, and III 43014, funded and implemented under the auspices of the Ministry of Education, Science and Technological Development, the Republic of Serbia.

\section{REFERENCES}

1. Council Directive $75 / 440 / \mathrm{EEC}$ of 16 June 1975 concerning the quality required of surface water intended for the abstraction of drinking water in the Member States. OJ L 194, 25.7.1975.

2. Council Directive 91/271/EEC of 21 May 1991 concerning urban waste-water treatment. OJ L 135, 30.5.1991. 
3. Council Directive 91/676/EEC of 12. December 1991 concerning the protection of waters against pollution caused by nitrates from agricultural sources. OJ L 375, 31.12.1991.

4. Council Directive 98/83/EC of 3. November 1998 on the quality of water intended for human consumption. OJ L 330, 5.12.1998.

5. Council Directive 2006/7/EC of 15 . February 2006 concerning the management of bathing water quality and repealing Directive 76/160/EEC. OJ L 64, 4.3.2006.

6. Directive 2000/60/EC of the European Parliament and of the Council establishing a framework for Community action in the field of water policy, EU Water Framework Directive.

7. Ministry of Agriculture and Environmental Protection, Serbian Environmental Protection Agency, Annual Report: The results of the quality of surface and groundwater for 2016, Belgrade 2017.

8. Ž. Vranjanac, D. Vasović, "Importance of oxygen regime indicators - case study of the Nišava river in Serbia", Facta Universitatis, Series: Working and Living Environmental Protection, 14 (2), 2017, pp. 181 - 186, https://doi.org/10.22190/FUWLEP1702181V, ISSN 0354-804X.

9. S. Stevanović, A. Savić, "Biological and microbiological monitoring of the quality of the river Nišava", Facta Universitatis, Series: Working and Living Environmental Protection, 15 (3), 2018, pp. 203 - 208, https://doi.org/ 10.22190/FUWLEP1803203S, ISSN 0354-804X.

10. Regulation on the parameters of the ecological and chemical status of surface water and the parameters of the chemical and quantitative status of groundwater, "Official Gazette of the RS", No. 74/2011.

11. Regulation on determining the water bodies of surface water and groundwater "Official Gazette of the RS", No. 50/2012.

12. The city of Niš wastewater treatment plant feasibility study - revisited version, 2017 .

13. Regulation on reference conditions of surface water types, "Official Gazette of the RS", No 67/2011.

14. Regulation on limit values for pollutants in surface and groundwater and sediments and deadlines for their achievement, "Official Gazette of the RS", No 50/2012.

15. National strategy for water management until 2034. "Official Gazette of the RS", No 3/2017.

16. D. Vasović, "Hybrid model of environmental capacity management". Doctoral dissertation. University of Niš, Faculty of Occupational Safety in Niš, 2016.

\section{ANALIZA ASPEKATA ŽIVOTNE SREDINE VELIKIH POSTROJENJA ZA TRETMAN OTPADNIH VODA NA PRIMERU GRADA NIŠA}

Republika Srbija se danas nalazi pri dnu lestvice evropskih zemalja u pogledu komunalne opremljenosti odnosne komunalne infrastructure u oblasti prikupljanja i tretmana otpadnih voda. Aktuelno stanje u oblasti upravljanja vodnim resursima u Republici Srbiji ukazuje da su osnovni problemi nedovoljna izgrađenost kanalizacione infrastrukture u gradovima, tj. nedovoljna pokrivenost kanalizacionom mrežom korisnika koji su priključeni na mrežu javnog ili privatnog vodosnabdevanja a zatim nedovoljna izgradjenost postrojenja za tretman otpadnih voda. U ovom smislu poseban problem predstavlja zahtev za relativno velikim inicijalnim ulaganjima $u$ sektor prikupljanja i tretmana otpadnih voda. Posebnu poteškoću predstavlja i niska cena isporučene i kanalisane vode u sistemu komunalnih delatnosti, koje nije dovoljna da obezbedi ni održavanje postojećih vodovodnih i kanalizacionih sistema $i$ generiše razvoj $i$ unapređenja postojećeg sistema. U Srbiji se trenutno tretira samo oko $10 \%$ otpadnih voda, različitim postupcima $i$ sa neujednačenim i, najčešće, nedovoljnim efektom prečišćavanja. Pored otpadnih voda stanovništva, poseban problem predstavlja $i$ neodgovarajući tretman industrijskih otpadnih voda. Takodje, dispozicija tretiranih voda, dispozicija izdvojenog mulja, kontrola smrada $i$ insekata, kontrola buke, radni uslovi, itd. predstavljaju značajne izazove. Stoga je i cilj ovog rada kompleksno sagledavanje svih aspekata životne sredine na primeru jednog velikog postrojenja za tretman otpadnih voda kakvo će biti ono koje tek treba da dobije grad Niš.

Ključne reči: velika postrojenja za tretman otpadnih voda, uticaj na životnu sredinu, grad Niš 